\title{
SHRIMP U-Pb and U-Pb Laser Ablation Geochronological on Zircons from Monte Santo Alkaline Intrusive Suite, Westhern Araguaia Belt, Tocantins State, Brazil
}

\author{
Rúbia Ribeiro Viana, Gislaine Amorés Battilani \\ Department of Mineral Resource, Federal University of Mato Grosso, Cuiabá, Brazil \\ Email: $\underline{\text { rrviana@gmail.com, gislaine@ufmt.br }}$
}

Received April 2014

\begin{abstract}
The Monte Santo Alkaline Intrusive Suite (MSAIS) is an association syenite foid, nepheline syenite and syenite, which are intruded in metapelites of the Rio do Coco meta-volcanic-sedimentary Sequence, presenting abundant pegmathoid veins cutting all of them. The ages obtained by Shrimp $(1051 \pm 22 \mathrm{Ma}, 1048 \pm 11 \mathrm{Ma})$ are very close those younger age obtained by U-Pb laser ablation (1056 \pm 21$)$, beeing interpreted as crystallization age. These dating reveal also that MSAIS rocks were affected by common succession of younger events below $550 \mathrm{Ma}$ ago, responsible by the later rocky bodies of varying composition occurring in the region, including the alkaline pegmatites hosted in the nepheline syenite of the MSAIS.
\end{abstract}

\section{Keywords}

Alkaline Rocks, Shrimp Dating, Tocantins Structural Province, Neoproterozoic, Brazil

\section{Introduction}

Ancient alkaline rocks exposure is not common. There are few alkaline complexes such as the Canadian Shield (Superior Province), Greenland, Australia (Yilgarn Block) and South Africa is known. The oldest are found in Kirkland Lake region, Canada, dated of $2.7 \mathrm{Ga}$, represented by tracytos and leucite fonolite. As the generation the Neoproterozoic and Phanerozoic alkaline rocks occur in three main geodynamic settings: 1) continental rifts, 2) oceanic islands, and 3) subduction zones (peralkaline granites in back-arc zones). The Early Precambrian alkaline rocks formed at hotspots of the oceanic crust and are unknown in continental rifts (Sheth et al., 2002, Bonin, 1998; Blichert-Toft et al., 1996).

Ancient alkaline rocks are difficult to understand due to most Archean rocks are metamorphosed and some have undergone severe hydrothermal alteration, resulting in the destruction of the alteration-sensitive feldspathoids or alkaline mafic minerals that are diagnostic of alkaline magmatism. Alkaline lavas also may lose part of their alkalis and as a result appear more like ordinary tholeiites (Blichert-Toft et al., 1996).

How to cite this paper: Viana, R. R., \& Battilani, G. A. (2014). SHRIMP U-Pb and U-Pb Laser Ablation Geochronological on Zircons from Monte Santo Alkaline Intrusive Suite, Westhern Araguaia Belt, Tocantins State, Brazil. Journal of Geoscience and Environment Protection, 2, 170-180. http://dx.doi.org/10.4236/gep.2014.23022 
Precambrian alkaline rocks are sparsely distributed and outcrop relatively small areas scattered from north to south Brazil. These are not many studies about these rocks, being the main in alkalines rocks of Bahia (720 \pm 9 to $732 \pm 24$ Ma Rosa et al., 2002, 2006; $2111 \pm 13$ Ma, Rios et al., 2007, $721 \pm$ Ma Conceição et al., 2009), Rio Grande do Sul (615 \pm 99 and $611 \pm 3$ Ma, Soliani Jr et al. 2000, Philipp et al. 2002), Pará (580 \pm 10 and $724 \pm$ 30 Ma, Jorge-João, 1980; Villas, 1982), Paraíba (ca. 600 to 580 Ma, Holland et al., 2009) and Tocantins (ca. 1500 Ma, Kitajima, 2002; Iwanuch, 1991).

In the Tocantins State, center-west of Brazil, are known three alkaline suites named of Estrela, Peixe and Monte Santo, therefore few detail studies of the petrogenetic and geochronological aspect were performed. This work is an attempt to characterize the age of the magmatism of the Monte Santo Alkaline Intrusive Suite (MSAIS), based in dating performed by Shrimp and laser ablation methods.

\section{Geological Setting}

The alkaline rocks studied in this work are positioned in the Tocantins Structural Province defined by Almeida (1977) and placed between San Francisco and Amazon Cratons. According to Pimentel et al. (2000) the Tocantins Structural Province represents a Brazilian orogen system characterized by belts of folds and thrusts called Brasilia, Paraguay and Araguaia belts, resulting from the convergence and collision of three continental blocks: the Amazon, San Francisco and Paranapanema cratons. In the study area neoproterozoic and basement rocks are partially covered by phanerozoic sediments of the Parnaíba Basin (Fuck et al., 2001). Paleoproterozoic basement rocks were partially reworked during the Brazilian orogeny (Pimentel et al., 2000).

The basement rocks in the area are represented by the core cratonic rocks with estimated ages between the Archean and Paleoproterozoic. It is composed by a granite-gneiss terrain affected by medium to high metamorphic degree associated with a metavolcanic-sedimentary sequence of the greenschist facies. According to Frasca \& Araújo (2001) the cratonic unit represents the evolution of a portion of the rejuvenated crust re-mobilized and stabilized during the Paleoproterozoic. Structural features suggest a crustal unit independent represented by the Granite-Gneissic Rio dos Mangues Complex and by metavolcano-sedimentary Rio do Coco Sequence.

Frasca \& Araújo (2001) reported that Monte Santo Alkaline Intrusive Suite is intruded in metapelites of the Rio do Coco meta-volcanic-sedimentary Sequence and in the Baixo Araguaia Group while Estrela Alkaline Suite outcrops accordingly with the rocks of the Rio dos Mangues Complex (Figure 1). Geochronological studies on zircons from syenitic gneisses by $\mathrm{Pb}-\mathrm{Pb}$ method carried out by Souza \& Moura (1996), indicated crystallization minimum ages of $1011 \pm 86 \mathrm{Ma}$, interpreted as evidence of the beginning of the rifting process that generated the basin in which is deposited the Baixo Araguaia Group.

\section{Analytical Techniques}

In situ U-Pb analyses were performed on a SHRIMP-II instrument in the Center of Isotopic Research (CIR) at VSEGEI, Saint Petersburg, Russia. The results were obtained with a secondary electron multiplier in peakjumping mode following the procedure described by Williams (1998). A primary beam of molecular oxygen was employed to bombard zircon in order to extract secondary ions. A $70 \mu \mathrm{m}$ Kohler aperture allowed focusing of the primary beam so that the ellipse-shaped analytical spot had a size ca $25 \mu \mathrm{m} \times 20 \mu \mathrm{m}$, and the corresponding ion current was $5 \mathrm{nA}$. The sputtered secondary ions were accelerated at $10 \mathrm{kV}$. The $80 \mu \mathrm{m}$ wide slit of the secondary ion source, in combination with a $100 \mu \mathrm{m}$ multiplier slit, allowed mass-resolution $\mathrm{M} / \Delta \mathrm{M} \geq 5000$ (1\% valley); thus, all the possible isobaric interferences were resolved. One minute rastering over a rectangular area of ca. $65 \mu \mathrm{m} \times 50 \mu \mathrm{m}$ was employed before each analysis in order to remove the gold coating and any possible surface common $\mathrm{Pb}$ contamination. The following ion species were measured in sequence: $196\left(\mathrm{Zr}_{2} \mathrm{O}\right)-204 \mathrm{~Pb}-$ background (ca 204 AMU)-206Pb-207Pb-208Pb-238U-248ThO-254UO with integration time ranging from 2 s to $14 \mathrm{~s}$. Seven cycles for each analyzed spot were acquired. Apart from "unknown” zircons, each fourth measurement was carried out on the zircon Pb/U standard TEMORA 1, which has an accepted 206Pb/238U age of $416.75 \pm 0.24 \mathrm{Ma}$ (Black et al., 2003). The 91500 zircon standard, with U concentration of $81.2 \mathrm{ppm}$ and a 206Pb/238U age of 1062 Ma (Wiedenbeck et al., 1995) was applied as the "U-concentration" standard. The results collected were then processed with the SQUID 1.02 (Ludwig, 2001) and Isoplot/Ex 3.00 (Ludwig, 2003) software, using the decay constants of Steiger and Jäger (1977). The common lead correction was done on the basis of measured 204Pb/206Pb and modern (i.e. $0 \mathrm{Ma}$ ) Pb isotope composition, according to the model of Stacey and Kramers (1975). 


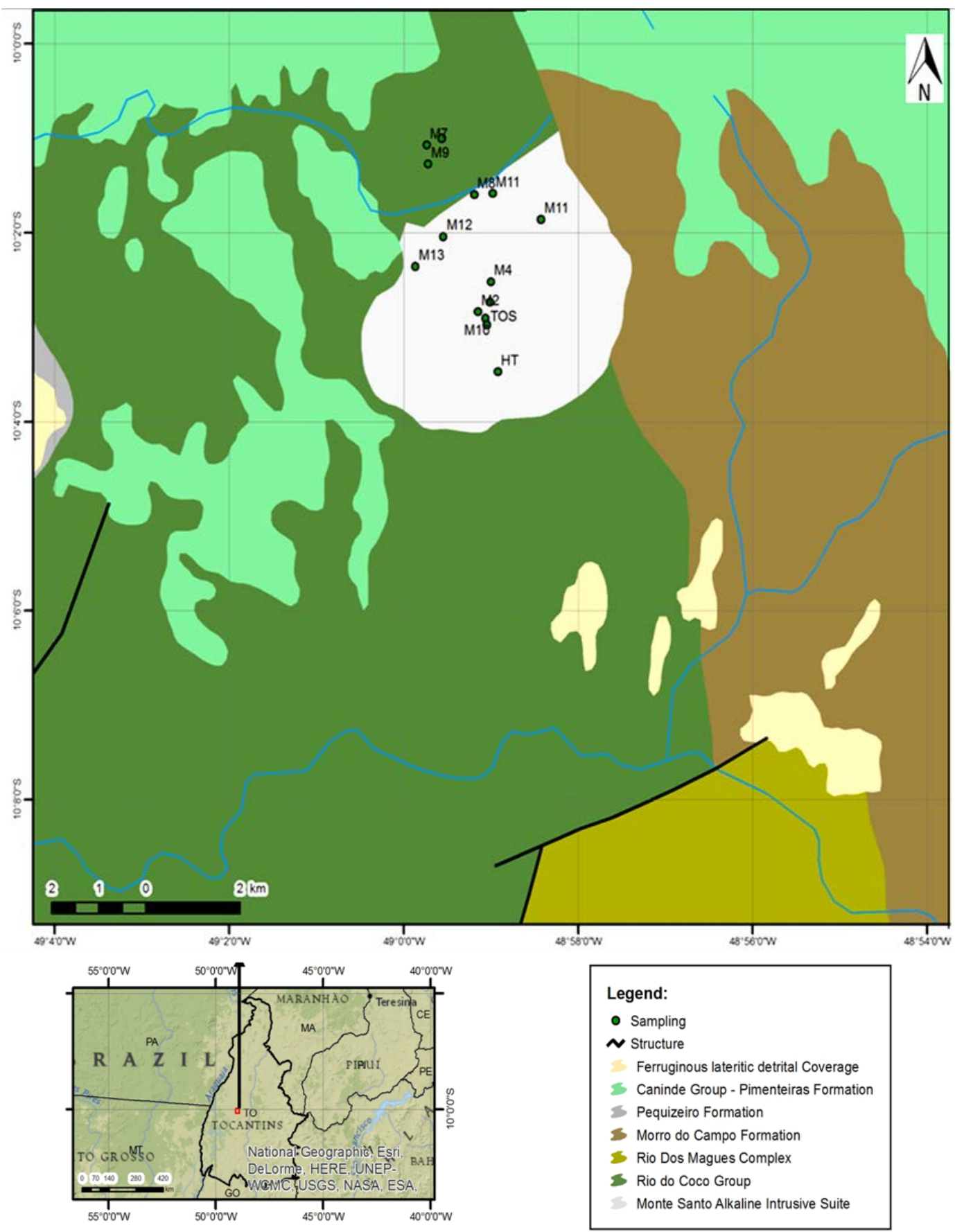

Figure 1. Geological sketch map of the Monte Santo Alkaline Intrusive Suite and adjacent rocks, Araguaia Belt, showing sample locations (modified from Gorayeb et al. (1996)).

The LA-MC-ICPMS analyses were performed in the Geological Survey of Finland where the chosen zircon grains were mounted in epoxy resin and sectioned approximately in half and polished. Back-scattered electron images (BSE) and cathodo luminescence (CL) images were prepared for the zircons to target the spot analysis sites. U-Pb dating analyses were performed using a Nu Plasma HR multicollector ICPMS in Espoo using a technique very similar to Rosa et al. (2009) except that a New Wave UP193 Nd: YAG laser microprobe was used. Samples were ablated in He gas (gas flow $=1.0 \mathrm{l} / \mathrm{min}$ ) using a low volume teardrop-shaped $\left(<2.5 \mathrm{~cm}^{3}\right.$ ) laser ablation cell (Horstwood et al., 2003). Raw data were corrected for background, laser induced elemental fractiona- 
tion, mass discrimination and drift in ion counter gains and reduced to $\mathrm{U}-\mathrm{Pb}$ isotope ratios by calibration to concordant reference zircons of known age, using protocols adapted from Andersen et al. (2004) and Jackson et al. (2004). Standard zircon GJ-01 (609 \pm 1 Ma; Belousova et al., 2006) and an in-house standard A1772 (2711 \pm $3 \mathrm{Ma} / \mathrm{TIMS} ; 2712 \pm 1 \mathrm{Ma} / \mathrm{SIMS}$ ) were used for calibra-tion. For reference, either zircon A382 (1877 $\pm 2 \mathrm{Ma}$, Patchett and Kouvo, 1986) or A1933 (TIMS/1641 \pm 2 Ma, SIMS/1640 \pm 4 Ma) was run as an unknown to check the calibration. The calculations were done off-line, using an interactive spreadsheet pro-gram written in Microsoft Excel/VBA by Tom Andersen (Rosa et al., 2009).

Plotting of the U-Pb isotopic data and age calculations were performed using the Isoplot/Ex 3 program (Ludwig, 2003). All the ages were calculated with $2 \sigma$ errors and without decay constants errors. Data-point error ellipses in the figures are at the $2 \sigma$ level.

\section{Description of the Selected Samples}

A total of three samples (named of $\mathrm{ABX}, \mathrm{HPO}_{2}$ and HTOSN) were analyzed for the geochronology by Shrimp with two them also analyzed by laser ablation (ABX and HTOSN). All the samples present similar zircons with most of which preserved terminations. The backscattered electron (BSE) and cathodoluminescence (CL) imaging showed that larger grains have normally euhedral forms and can to present more deformed internal structure with a typical magmatic concentric or oscillatory zoning, while the smaller grains shows more altered blurry internal structure, sometimes presenting massive interior structure to zoning marginal domain (Figure 2).

\section{Results and Discussion}

Five grains of zircon from the sample ABX were analyzed by shrimp (Table $\mathbf{1}$ and Figure 3) and three grains using MC-LA-ICP-MS (Table 2). The Shrimp analyses showed that from five grains analyzed two of them (grains 2 and 3, Table 1) have two real ages of $1051+/-20$ and $402+/-20$ Ma (Figure 3(a)). All points of the
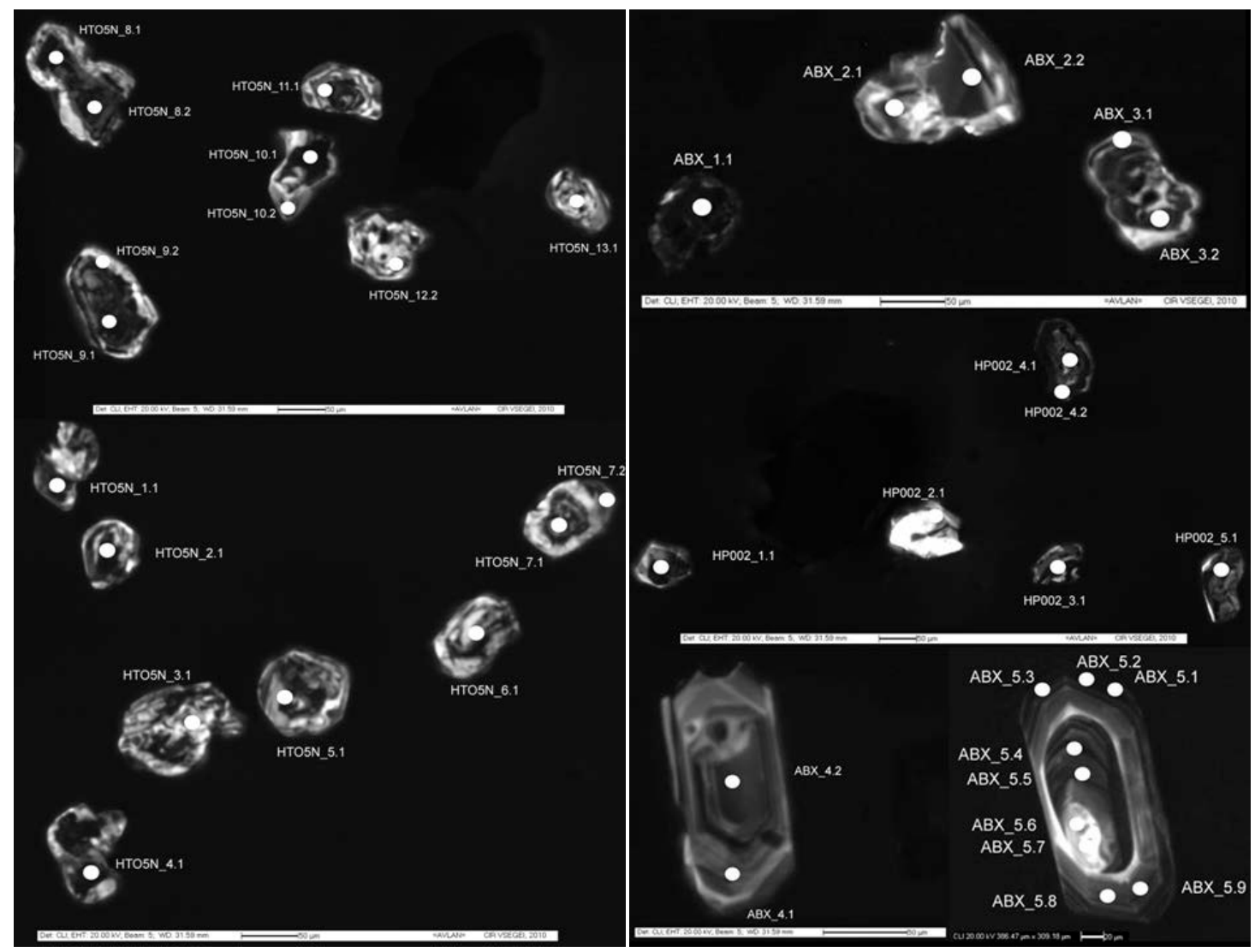

Figure 2. Cathodoluminescence images of selected zircon crystals separated from the studied rocks. 


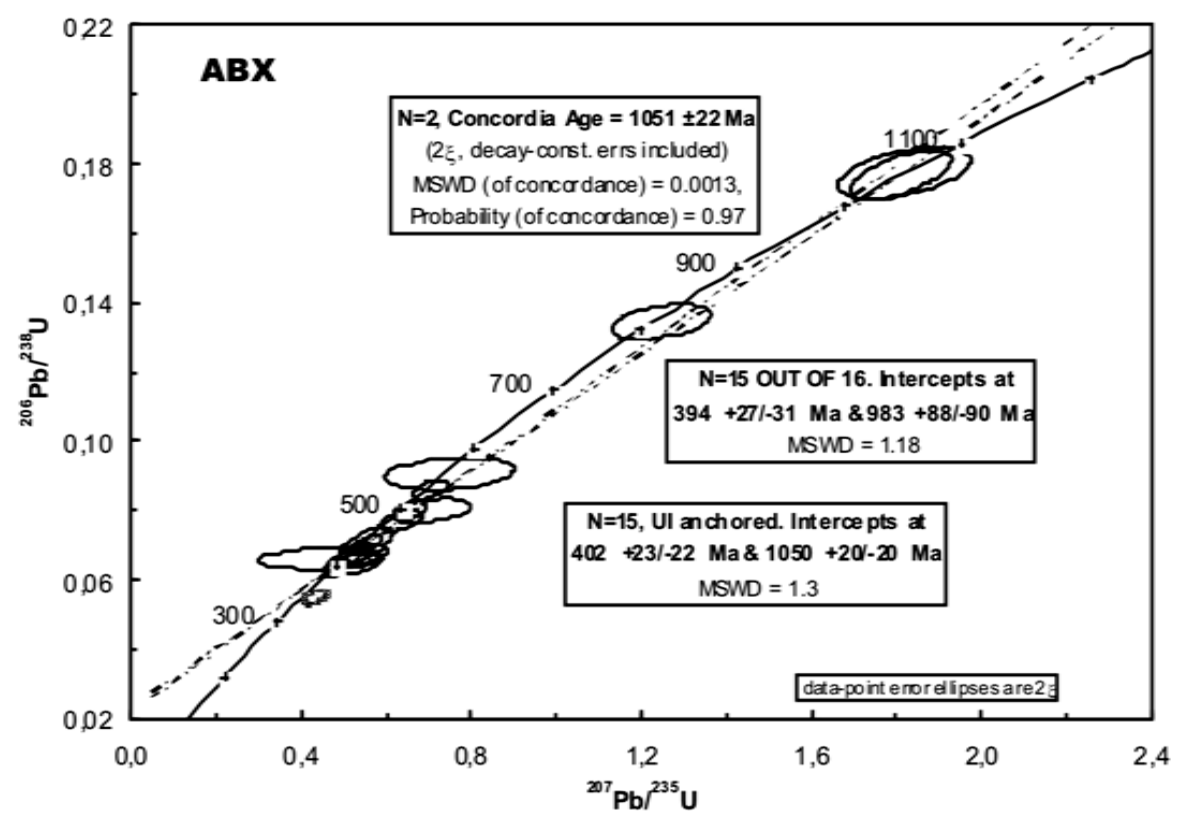

(a)

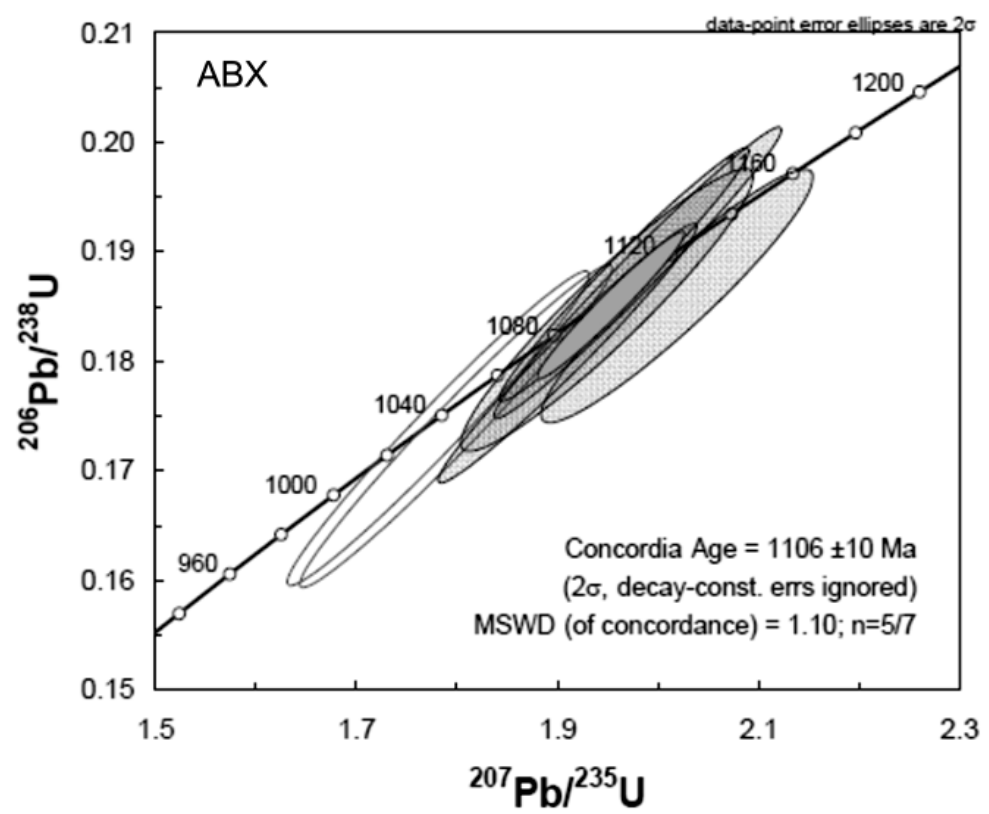

(b)

Figure 3. SHRIMP Zircon U-Pb Concordia plots and recalculated weighted mean 206Pb/238U ages (a) and MC-LA-ICPMS U-Pb (b) isotopic data for sample ABX from MSAIS rocks.

other grains analyzed showed ages close to those younger ages. The event of $520 \mathrm{Ma}$ is not clearly registered. A big grain (grain 05) with nine spots analyzed, illustrate event of 400 - 420 Ma old (Figure 3(a)). By MC-LAICP-MS analyses, five analyses were done on the large grain and two on both the smaller grains, in which produced age of $\sim 1100$ Ma age for the two different types of zircon (Table 2, Figure 3(b)). In Table 2 is also observed two discordant data points, it is not plotted in diagram.

From sample HTOS seventeen zircon grains were produced, in which thirteen were analyzed by shrimp (Table 1) and only four by MC-LA-ICP-MS (Table 2). Most of the zircon show many metamictic portions. The 
Table 1. SHRIMP isotopic data for Zircon of the rocks from Monte Santo Alkaline Intrusive Suite.

\begin{tabular}{|c|c|c|c|c|c|c|c|c|c|c|c|c|c|c|c|c|c|c|c|}
\hline \multirow{2}{*}{$\begin{array}{c}\begin{array}{c}\text { Sample/ } \\
\text { spot }\end{array} \\
\text { ABX_1.1 }\end{array}$} & \multirow{2}{*}{$\begin{array}{c}\begin{array}{c}\text { \% } \\
{ }^{206} \mathbf{P b}_{\mathbf{c}}\end{array} \\
0.41\end{array}$} & \multirow{2}{*}{$\begin{array}{c}\mathbf{p p m} \\
\mathbf{U} \\
853\end{array}$} & \multirow{2}{*}{$\begin{array}{r}\begin{array}{c}\text { ppm } \\
\text { Th }\end{array} \\
508\end{array}$} & \multirow{2}{*}{$\begin{array}{c}{ }^{206} \mathbf{P b}^{*} \\
63.1\end{array}$} & \multirow{2}{*}{$\begin{array}{c}{ }^{232} \mathrm{Th} \\
0.62\end{array}$} & \multicolumn{2}{|c|}{$\begin{array}{l}(\mathbf{1 )} \\
{ }^{206} \mathbf{P b} \\
{ }^{238} \mathrm{U} \\
\text { Age }\end{array}$} & \multicolumn{2}{|c|}{$\begin{array}{c}(1) \\
{ }^{207} \mathbf{P b} \\
{ }^{206} \mathbf{P b} \\
\text { Age }\end{array}$} & \multirow{2}{*}{ 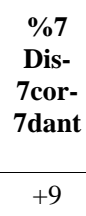 } & \multicolumn{2}{|c|}{$\begin{array}{c}{ }^{(1)} \\
{ }^{238} \mathbf{U} \\
{ }^{206} \mathbf{P b}\end{array}$} & \multicolumn{2}{|c|}{$\begin{array}{c}\stackrel{(1)}{ }_{{ }^{207} \mathbf{P b}^{*}}{ }^{206} \mathbf{P b}^{*} \\
\pm \%\end{array}$} & \multicolumn{2}{|c|}{$\begin{array}{c}{ }^{(1)} \\
\frac{}{207} \mathbf{P b}^{*}{ }^{*} \mathbf{U} \\
\pm \%\end{array}$} & \multicolumn{2}{|c|}{ 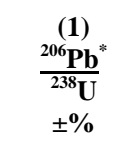 } & \multirow{2}{*}{$\begin{array}{l}\frac{1}{2} \\
3 \\
3 \\
3\end{array}$} \\
\hline & & & & & & 532 & \pm 7 & 581 & \pm 43 & & 11.6 & 1.3 & 0.0594 & 2.0 & 0.70 & 2.4 & 0.086 & 1.3 & \\
\hline ABX_2.1 & 0.73 & 49 & 81 & 3.79 & 1.73 & 560 & 11 & 60 & \pm 175 & +7 & 11.0 & 2.1 & 0.0599 & 8.1 & 75 & 3 & 0.091 & 2.1 & 0.2 \\
\hline ABX_2.2 & 0.09 & 124 & 235 & 18. & 1.96 & 1050 & \pm 16 & 10 & \pm 42 & -0 & 7 & 1.6 & 0.0743 & 2.1 & 1.81 & .7 & 0.177 & 6 & c \\
\hline ABX_3.1 & 0.39 & 143 & 236 & 16.5 & 1.71 & 813 & \pm 12 & 848 & \pm 72 & + & .4 & 1.6 & 0.0673 & 3.5 & 1.25 & 3.8 & 0.134 & .6 & 0.4 \\
\hline ABX_3.2 & 0.36 & 112 & 594 & 17.1 & 5.48 & 1053 & \pm 17 & 1051 & \pm 62 & -0 & 6 & 1.7 & 0.0744 & 3.1 & 1.82 & .5 & 0.177 & 1.7 & 0.5 \\
\hline ABX_4.1 & -- & 86 & 58 & 5.87 & 0.70 & 495 & \pm 8 & 746 & \pm 107 & +35 & 12.5 & 1.8 & 0.0641 & 5.1 & 0.71 & 5.4 & 0.080 & 1.8 & 0.3 \\
\hline ABX_4.2 & 0.00 & 141 & 221 & 9.33 & 1.62 & 478 & \pm 7 & 603 & \pm 59 & +2 & 13.0 & 1.6 & 0.0600 & 2.7 & 0.64 & 3.1 & 0.077 & 1.6 & 0.5 \\
\hline ABX_5.1 & 0.41 & 1475 & 340 & 69.5 & 0.24 & 344 & \pm 5 & 493 & \pm 52 & +31 & 18.2 & 1.4 & 0.0570 & 2.4 & 0.43 & 2.7 & 0.055 & 1.4 & 0.5 \\
\hline ABX_5.2 & -- & 702 & 246 & 42.5 & 0.36 & 439 & \pm 6 & 507 & \pm 43 & +14 & 14.2 & 1.5 & 0.0574 & 1.9 & 0.56 & 2.4 & 0.070 & 1.5 & 0.6 \\
\hline ABX_5.3 & -- & 678 & 231 & 46.4 & 0.35 & 495 & \pm 7 & 598 & \pm 38 & +18 & 12.5 & 1.5 & 0.0599 & 1.8 & 0.66 & 2.3 & 0.080 & 1.5 & 0.6 \\
\hline ABX_5.4 & 0.34 & 403 & 115 & 24.2 & 0.29 & 436 & \pm 13 & 497 & \pm 78 & +13 & 14.3 & 3.0 & 0.0571 & 3.5 & 0.55 & 4.7 & 0.070 & 3.0 & 0.7 \\
\hline ABX_5.5 & 0.17 & 553 & 134 & 31.9 & 0.25 & 419 & \pm 6 & 485 & \pm 56 & +14 & 14.9 & 1.5 & 0.0568 & 2.5 & 0.53 & 2.9 & 0.067 & 1.5 & 0.5 \\
\hline ABX_5.6 & 1.28 & 118 & 49 & 6.69 & 0.43 & 411 & \pm 8 & 153 & \pm 312 & -174 & 15.2 & 1.9 & 0.0491 & 13.3 & 0.45 & 13.4 & 0.066 & 1.9 & 0.1 \\
\hline ABX_5.7 & 0.00 & 100 & 38 & 5.52 & 0.39 & 403 & \pm 7 & 563 & \pm 95 & +29 & 15.5 & 1.9 & 0.0589 & 4.4 & 0.52 & 4.7 & 0.065 & 1.9 & 0.4 \\
\hline ABX_5.8 & 0.26 & 352 & 165 & 20.3 & 0.49 & 420 & \pm 6 & 591 & \pm 71 & +30 & 14.9 & 1.5 & 0.0597 & 3.3 & 0.55 & 3.6 & 0.067 & 1.5 & 0.4 \\
\hline ABX_5.9 & 0.00 & 470 & 192 & 26.4 & 0.42 & 408 & \pm 12 & 423 & \pm 55 & +4 & 15.3 & 3.0 & 0.0553 & 2.5 & 0.50 & 3.9 & 0.065 & 3.0 & 0.8 \\
\hline HTOS_1.1 & 0.19 & 308 & 413 & 46.9 & 1.39 & 1052 & \pm 17 & 1050 & \pm 59 & -0 & 5.6 & 1.7 & 0.0743 & 2.9 & 1.82 & 3.4 & 0.177 & 1.7 & 0.5 \\
\hline HTOS_2.1 & 0.17 & 384 & 461 & 57.8 & 1.24 & 1041 & \pm 16 & 1126 & \pm 30 & +8 & 5.7 & 1.7 & 0.0772 & 1.5 & 1.87 & 2.3 & 0.175 & 1.7 & 0.7 \\
\hline HTOS_3.1 & 0.18 & 158 & 106 & 12.4 & 0.69 & 563 & \pm 9 & 593 & \pm 78 & +5 & 11.0 & 1.6 & 0.0597 & 3.6 & 0.75 & 4.0 & 0.091 & 1.6 & 0.4 \\
\hline HTOS_4.1 & -- & 395 & 187 & 58.8 & 0.49 & 1029 & \pm 16 & 1046 & \pm 28 & +2 & 5.8 & 1.7 & 0.0742 & 1.4 & 1.77 & 2.2 & 0.173 & 1.7 & 0.8 \\
\hline HTOS_5.1 & 0.59 & 80 & 19 & 9.39 & 0.25 & 821 & \pm 14 & 921 & \pm 99 & +11 & 7.4 & 1.8 & 0.0697 & 4.8 & 1.31 & 5.1 & 0.136 & 1.8 & 0.4 \\
\hline HTOS_6.1 & 1.06 & 67 & 71 & 10.1 & 1.10 & 1051 & \pm 19 & 1019 & \pm 115 & -3 & 5.6 & 1.9 & 0.0732 & 5.7 & 1.79 & 6.0 & 0.177 & 1.9 & 0.3 \\
\hline HTOS_7.1 & -- & 313 & 159 & 38.5 & 0.52 & 862 & \pm 14 & 1001 & \pm 76 & +15 & 7.0 & 1.7 & 0.0725 & 3.7 & 1.43 & 4.1 & 0.143 & 1.7 & 0.4 \\
\hline HTOS_7.2 & -- & 241 & ? & 17 & 0.09 & 508 & \pm 7 & 582 & \pm 73 & +13 & 12.2 & 1.5 & 0.0594 & 3.4 & 0.67 & 3.7 & 0.082 & 1.5 & 0.4 \\
\hline HTOS_8.1 & 0.16 & 480 & 619 & 73.6 & 1.33 & 1058 & \pm 14 & 1071 & \pm 26 & +1 & 5.6 & 1.4 & 0.0751 & 1.3 & 1.85 & 1.9 & .178 & 1.4 & 0.7 \\
\hline HTOS_8.2 & 0.51 & 610 & 342 & 43.3 & 0.58 & 512 & \pm 7 & 550 & \pm 53 & +7 & 12.1 & 1.4 & 0.0585 & 2.4 & 0.67 & 2.8 & 0.083 & 1.4 & 0.5 \\
\hline HTOS_9.1 & 0.08 & 338 & 123 & 50.3 & 0.38 & 1031 & \pm 14 & 1012 & \pm 28 & -2 & 50 & 1.5 & 0.0729 & 1.4 & 1.74 & 20 & 173 & 1.5 & 0.7 \\
\hline HTOS_9.2 & -- & 31 & 305 & 35 & 1.00 & 796 & \pm 11 & 932 & \pm 41 & +1 & 7.6 & 1.5 & 0.0701 & 2.0 & 1.27 & 2 & 1 & 1.5 & 0.6 \\
\hline HTOS_10.1 & -- & 4 & 463 & 67.3 & 0.96 & 9 & \pm 12 & 104 & \pm 2 & +10 & 6.4 & 1.4 & 0.0741 & 1.1 & 1 & 1.7 & 57 & 1.4 & 0.8 \\
\hline HTOS_10.2 & 0.86 & 1 & 3 & 1. & 0 & 568 & \pm 9 & 553 & \pm 147 & -3 & 10.9 & 1.7 & 0.0586 & 6.7 & .74 & 0 & .092 & 1.7 & c \\
\hline HTOS11.1 & - & 340 & 298 & 51.8 & 0.91 & 1053 & \pm 14 & 1114 & \pm 33 & + & $ᄃ$ & 1.5 & 0.0767 & 1.6 & 1 & 2.2 & .177 & 1.5 & 0.7 \\
\hline HTOS_12.1 & 1.93 & 78 & 4 & 6.44 & 0.58 & 588 & \pm 12 & 354 & \pm 361 & -69 & 10.5 & 2.2 & 0.053 & 16.0 & 0.71 & 16.1 & 0.096 & 2.2 & 0.1 \\
\hline HTOS_13.1 & 1.34 & 195 & 255 & 15.8 & 1.35 & 581 & \pm 38 & 719 & \pm 121 & +20 & 10.6 & 6.9 & 0.0633 & 5.7 & 0.82 & 8.9 & .094 & 6.9 & 0.8 \\
\hline HP002_2.1 & 2.66 & 39 & 81 & 2.83 & 2.15 & 523 & \pm 18 & 170 & \pm 783 & -216 & 11.8 & 3.5 & 0.0495 & 33.5 & 0.58 & 33.7 & 0.085 & 3.5 & 0.1 \\
\hline HP002_6.1 & 29.37 & 3 & 19 & 0.132 & 6.24 & 301 & \pm 89 & 3293 & \pm 1213 & +93 & 20.9 & 30.3 & 0.2677 & 77.3 & 1.76 & 83.0 & 0.048 & 30.3 & 0.4 \\
\hline HP002_6.2 & 0.40 & 525 & 122 & 30.4 & 0.24 & 421 & \pm 6 & 683 & \pm 55 & +40 & 14.8 & 1.6 & 0.0623 & 2.6 & 0.58 & 3.0 & 0.068 & 1.6 & 0.5 \\
\hline HP002_4.1 & 3.48 & 398 & 696 & 24.1 & 1.81 & 440 & \pm 7 & 605 & \pm 201 & +28 & 14.2 & 1.6 & 0.0600 & 9.3 & 0.58 & 9.4 & 0.071 & 1.6 & 0.2 \\
\hline HP002_4.2 & 0.96 & 305 & 81 & 22.7 & 0.27 & 535 & \pm 8 & 540 & \pm 109 & +1 & 11.6 & 1.6 & 0.0583 & 5.0 & 0.69 & 5.2 & 0.086 & 1.6 & 0.3 \\
\hline HP002_1.1 & -- & 347 & 88 & 26.6 & 0.26 & 550 & \pm 8 & 544 & \pm 55 & -1 & 11.2 & 1.5 & 0.0584 & 2.5 & 0.72 & 2.9 & 0.089 & 1.5 & 0.5 \\
\hline HP002_5.1 & 0.25 & 218 & 136 & 30.9 & 0.64 & 985 & \pm 15 & 1020 & \pm 46 & +4 & 6.1 & 1.6 & 0.0732 & 2.3 & 1.67 & 2.8 & 0.165 & 1.6 & 0.6 \\
\hline HP002_3.1 & 0.00 & 356 & 146 & 53 & 0.42 & 1030 & \pm 14 & 1098 & \pm 25 & +7 & 5.8 & 1.5 & 0.0761 & 1.3 & 1.82 & 2.0 & 0.173 & 1.5 & 0.8 \\
\hline
\end{tabular}

Errors are 1-sigma; $\mathrm{Pb}_{\mathrm{c}}$ and $\mathrm{Pb}^{*}$ indicate the common and radiogenic portions, respectively. Error in Temora1 Standard calibration was $0.50 \%$. (1) Common $\mathrm{Pb}$ corrected using measured 204Pb. 


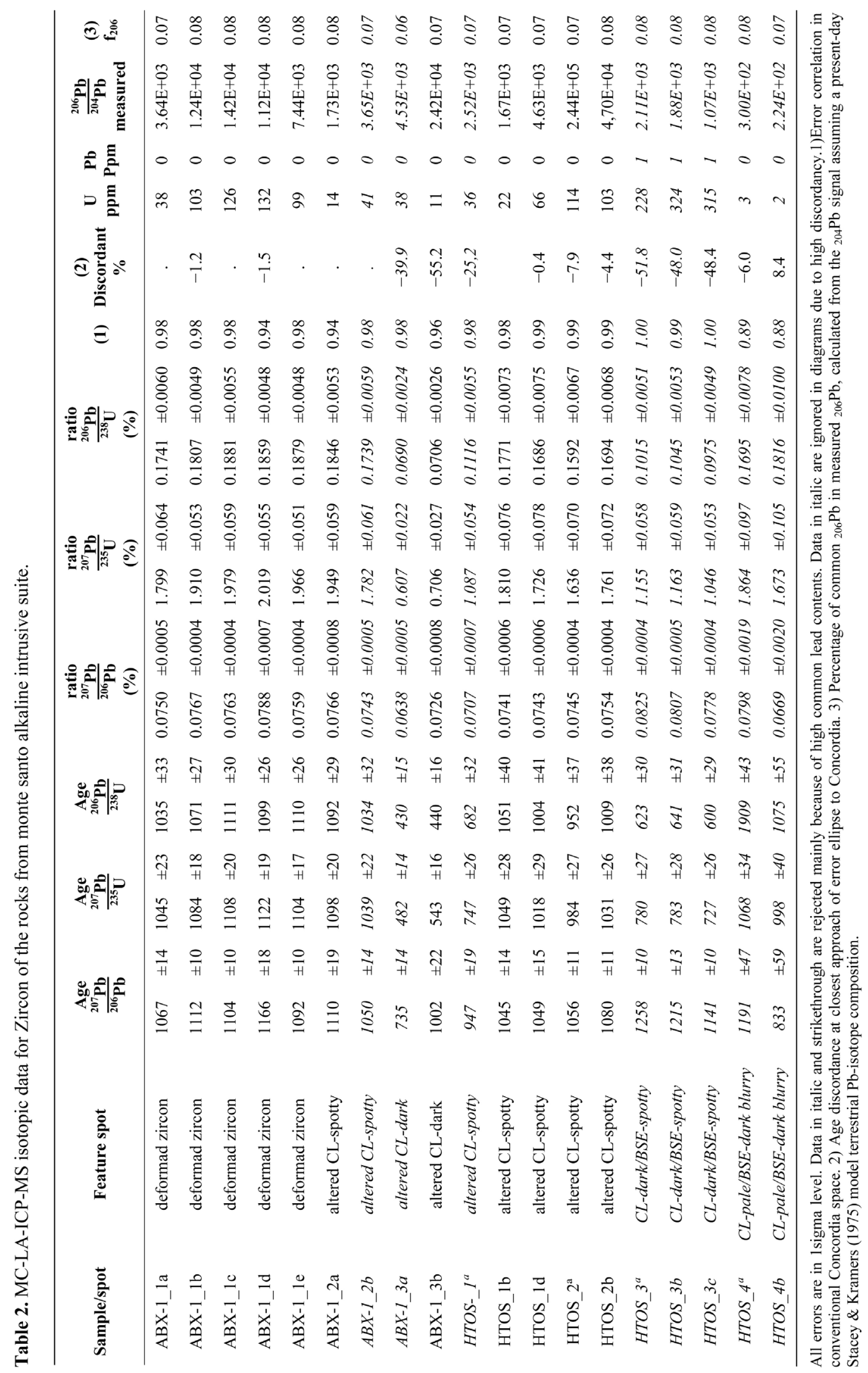


shrimp analyzed have a very good example of two ages in the single crystal, which is shown in grains 7, 8, 9 and 10 (Table 2). Both ages are concordant and are of $1048 \pm 11$ and $511 \pm 10$ Ma (Figure 4(a)). A total of ten MC-LA-ICP-MS analysis were realized and revealed all the spots analyzed of the zircon 03 and one from zircon 01 showed highly discordant age (Table 2). The remaining analyses produced equivalent $\mathrm{U}-\mathrm{Pb}$ age of approximating1060 Ma (Figure 4(b)).

The sample HPOO2 had their zircon analyzed only by Shrimp, in the total of six grains. The grain 4 is the unique that revel two real ages of $1030 \pm 14$ e another of $535 \pm 8$, Ma (Table 2, Figure 5). The last event is stronger and it was influenced for other younger (ca $420 \mathrm{Ma}$ ).

The ages obtained by MC-LA-ICP-MS and Shrimp method show ages very close. The studied samples were characterized by common succession of events, with the Shrimp crystallization age varying of $1051 \pm 22$ Ma and $1048 \pm 11 \mathrm{Ma}$ and MC-LA-ICP-MS ages varying of $1106 \pm 10 \mathrm{Ma}$ and $1056 \pm 21 \mathrm{Ma}$, with subsequent recrystallization during much younger process below 500 Ma ago.

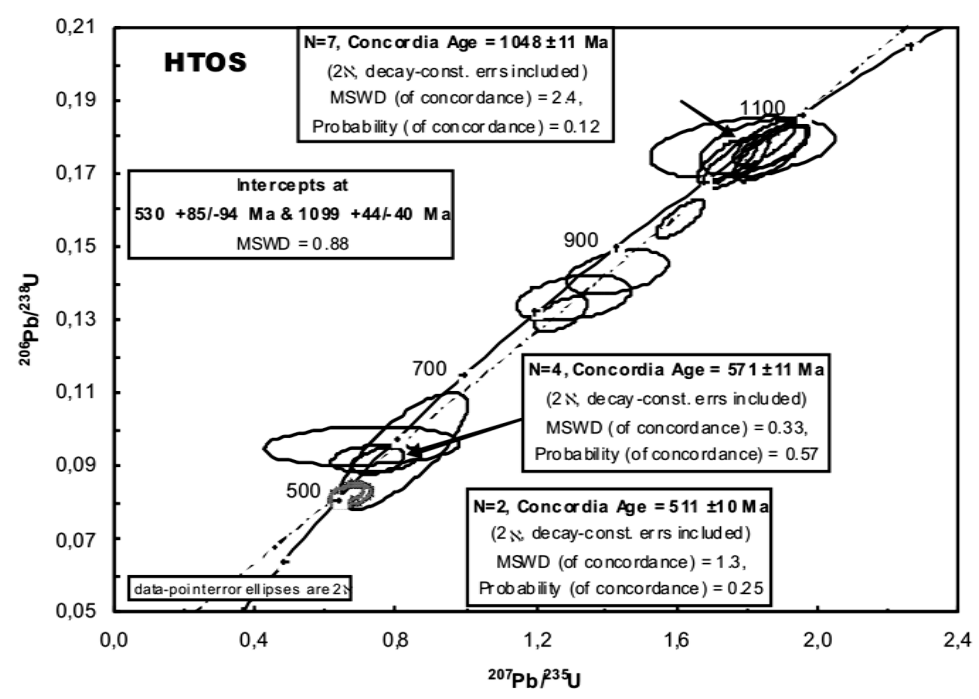

(a)

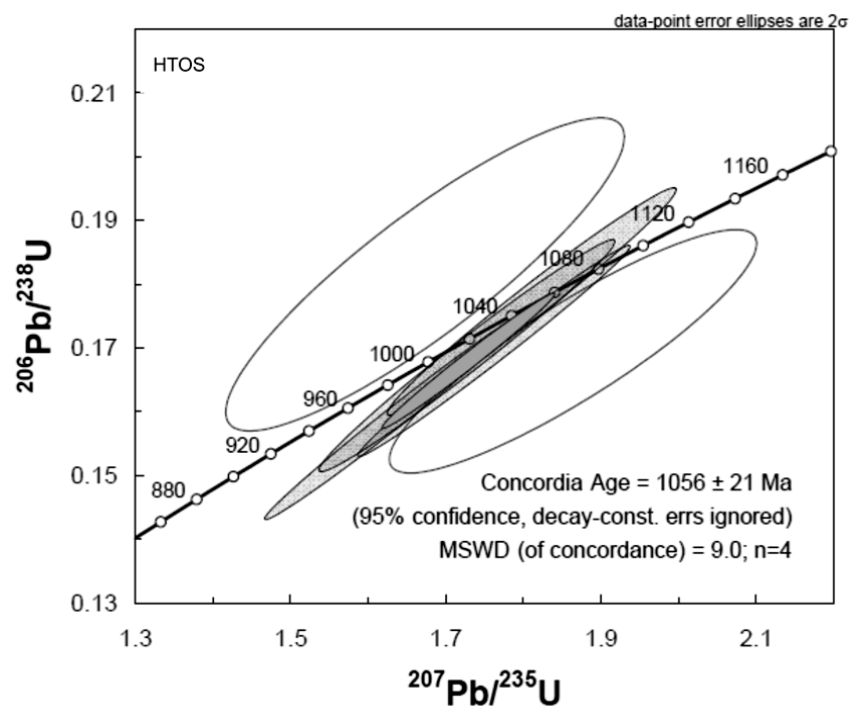

(b)

Figure 4. SHRIMP Zircon U-Pb Concordia plots and recalculated weighted mean $206 \mathrm{~Pb} / 238 \mathrm{U}$ ages (a) MC-LA-ICPMS U-Pb isotopic data for sample HTOS from MSAIS rocks. 


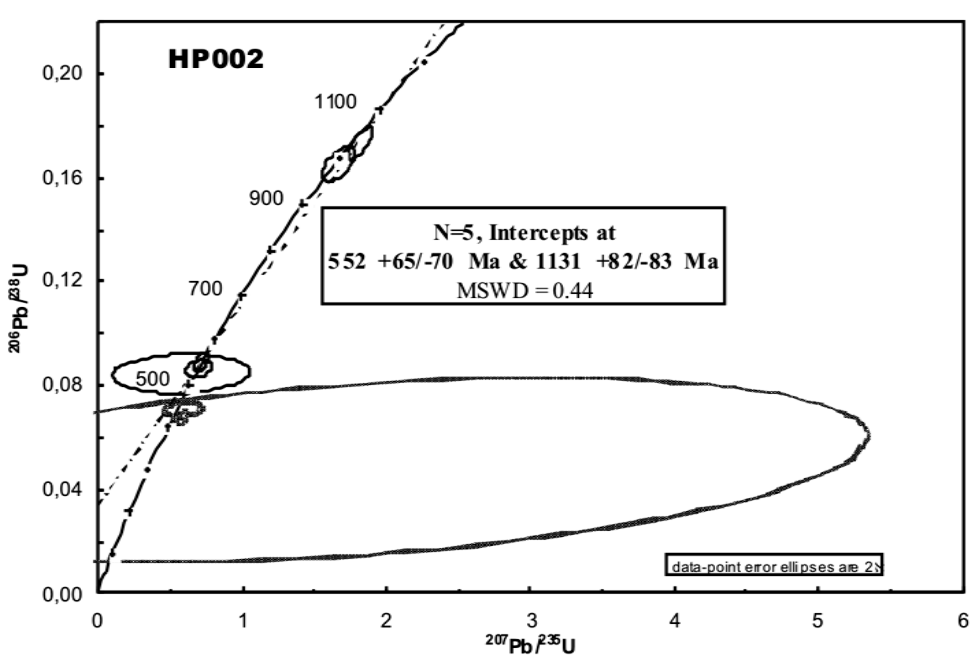

Figure 5. SHRIMP Zircon U-Pb Concordia plots and recalculated weighted mean $206 \mathrm{~Pb} / 238 \mathrm{U}$ ages.

We interpret the concordant older ages as recording the time of crystallization of zircon in the Alkaline Monte Santo Complex. Although some grains seems have been affected by cracks, no evidence from the analytical data was found to be anomalous.

The crystals subsequently affected by one or more episodes of lead loss, suggesting that the nepheline syenitic rocks have been involved in a thermo-tectonic episode, namely Brazilian Orogeny, in the end of the Neoproterozoic. These events are represented by concordant ages of $511 \pm 10,535 \pm 8$ and $402 \pm 20$ Ma and may have been responsible for the granitegenesis described by Alvarenga et al. (2000) in domain of Estrondo Group and also for the reactivation of numerous fractures occurred to south, as well as by the intense hydrothermal activity and metasomatic alterations in which modify the primary mineralogy of the rocks of the Monte Santo Alkaline Intrusive Suite. These episodes were also responsible by generation of the later bodies and including the alkaline pegmatites present in the area.

\section{Acknowledgements}

This work was partially supported by the Foundation for Research Support of the State of Mato Grosso (FAPEMAT) and National Scientific and Technological Development Council (CNPQ).

\section{References}

Almeida, F. F. M., Hasui, Y., Brito Neves, B. B., \& Fuck R. A. (1977). Províncias Estruturais Brasileiras. VIII Simpósio de Geologia do Nordeste, Campina Grande, Atas. Pernanbuco, SBG-Núcleo Nordeste, 1, 363-392.

Alvarenga, C. J. S., Moura, C. A. V., Gorayeb, P. S. S., \& Abreu, F. A. M. (2000). Paraguai and Araguaia belts. In U. G. Cordani, E. J. Milani, A. Thomaz Filho, \& D. A.Campos (Eds.), Tectonic Evolution of South America, 183-193.

Andersen, T., Griffin, W. L., Jackson, S. E., Knudsen, T.-L., \& Pearson, N. J. (2004). Mid-Proterozoic Magmatic Arc Evolution at the Southwest Margin of the Baltic Shield. Lithos, 73, 289-318. http://dx.doi.org/10.1016/j.lithos.2003.12.011

Belousova, E. A., Griffin, W. L., \& O’Reilly, S. Y. (2006). Zircon Crystal Morphology, Trace Element Signatures and HF Isotope Composition as a Tool for Petrogenetic Modeling: Examples from Eastern Australian Granitoids. Journal of Petrology, 47, 329-353. http://dx.doi.org/10.1093/petrology/egi077

Black, L. P., Kamo, S. L., Allen, C. M., Aleinikoff, J. N., Davis, D. W., Korsch, R. J., \& Foudoulis, C. (2003). TEMORA 1: a New Zircon Standard for Phanerozoic U-Pb Geochronology. Chemical Geology, 200, 155-170. http://dx.doi.org/10.1016/S0009-2541(03)00165-7

Blichert-Toft, J., Arndt N. T., \& Ludden, J. N. (1996). Precambrian Alkaline Magmatism. Lithos, 37, 97-111. http://dx.doi.org/10.1016/0024-4937(95)00031-3

Bonin, B., Azzouni-Sekkal, A., Bussy, F., \& Ferrag, S. (1998). Alkali-Calcic and Alkaline Post-Orogenic (PO) Granite Magmatism: Petrologic Constraints and Geodynamic Settings. Lithos, 45, 45-70. 
http://dx.doi.org/10.1016/S0024-4937(98)00025-5

Conceição, H., Rosa, M. L. S., Moura, C. A. V., Macambira, M. J. B., Galarza, M. A., Rios, D. C., Marinho, M. M., Menezes, R. C. L., \& Cunha, M. P. (2009). Petrology of the Neoproterozoic Itarantim Nepheline Syenite Batholith, São Francisco Craton, Bahia, Brazil. Can Mineral, 47, 1527-1550. http://dx.doi.org/10.3749/canmin.47.6.1527

Frasca, A. A. S., \& Araújo, V. A. (2001). Projeto Hidrogeologia no Tocantins—Folha Palmas—SD 22-Z-B. Goiânia: CPRM/Serviço Geológico do Brasil, 52 p.

Fuck, R. A., Dantas, E. L., Pimentel, M. M., Junges, S. L., \& Moraes, R. (2001). Nd isotopes, U-Pb single grain and SHRIMP zircon ages from basement rocks of the Tocantins Province. Proceedings of the III South American Symposium on Isotope Geology, Santiago, Extended Abstract, 141-144 (CD ROM).

Gorayeb P. S. S. (1996). Petrologia e evolução crustal das rochas de alto grau de Porto Nacional-TO. Tese de Doutorado. Belém: Instituto de Geociências, Universidade Federal do Pará, 258 p.

Holland, M. H. B. M., Mejía, C. P., Archanjo, C. J., \& Armstrong, R. (2009). Geologia e Caracterização Química do Magmatismo Peralcalino Ultrapotássico do Enxame de Diques Manaíra-Princesa Isabel, Província Borborema. Geol. USP, Sér. cient., São Paulo, 9, 13-46.

Horstwood, M. S. A., Foster, G. L., Parrish, R. R., Noble, S. R., \& Nowell, G. M. (2003). Common-Pb Corrected in Situ U-Pb Accessory Mineral Geochronology by LA-MC-ICP-MS. Journal of Analytical Atomic Spectrometry, 18, 837-846. http://dx.doi.org/10.1039/b304365g

Iwanuch, W. (1991). Geologia dos complexos alcalinos proterozóicos do centro do estado de Tocantins. Tese de Doutorado; São Paulo: Instituto de Geociências, Universidade de São Paulo, 202 p.

Jackson, S. E., Pearson, N. J., Griffin, W. L., \& Belousova, E. A. (2004). The Application of Laser Ablation-Inductively Coupled Plasma-Mass Spectrometry to In-Situ U-Pb Zircon Geochronology. Chemical Geology, 211, 47-69. http://dx.doi.org/10.1016/j.chemgeo.2004.06.017

Jorge-João, X. S. (1989) O litchfieldito Boca Nova no nordeste do Estado do Pará: Aspectos petroquímicos e implicação econômica. Belém: CPRM.

Kitajima, L. F. W. (2002). Mineralogia e petrologia do Complexo Alcalino de Peixe-Tocantins. Tese Instituto de Geociências, Universidade de Brasília.

Ludwig, K. R. (2001). SQUID 1.02, A User Manual, A Geochronological Toolkit for Microsoft Excel. Berkeley: Berkeley Geochronology Center Special Publication.

Ludwig, K. R. (2003). User's Manual for Isoplot/Ex, Version 3.00, A Geochronological Toolkit for Microsoft Excel. Berkeley: Berkeley Geochronology Center Special Publication.

Patchett, J., \& Kouvo, O. (1986). Origin of continental crust of 1.9-1.7 Ga age: Nd iso-topes and U-Pb zircon ages in the Svecokarelian terrain of south Finland. Contributions to Mineralogy and Petrology, 92, 1-12. http://dx.doi.org/10.1007/BF00373959

Philipp, R. P., Machado, R., Nardi, L. V. S., \& Lafon, J. M. (2002). O magmatismo granítico neoproterozóico do BatólitoPelotas no sul do Brasil: Novos dados e revisão da geocronologia regional. Rev Bras Geoc, 32, 277-290.

Pimentel, M. M., Fuck, R. A., Jost, H., Ferreira Filho, C. F., \& Araújo, S. M. (2000). The basement of the Brasília Fold Belt and the Goiás Magmatic Arc. In U. G. Cordani, E. J. Milani, A. Thomaz Filho, \& D. A. Campos (Eds.), Tectonic Evolution of South America (pp. 190-229). Rio de Janeiro: 31st IGC,

Rios, D. C., Conceição, H., Davis, D. W., Plá Cid, J., Rosa, M. L. S., Macambira, M. J. B., Mcreath, I., Marinho, M. M., \& Davis, W. J. (2007). Paleoproterozoic potassic-ultrapotassic magmatism: morro do afonso syenite pluton, bahia, brazil. Precambrian Research, 154, 1-30. http://dx.doi.org/10.1016/j.precamres.2006.11.015

Rosa, D. R. N., Finch, A. A., Andersen, T., \& Inverno, C. M. C. (2009). U-Pb Geochronology and Hf Isotope Ratios of Magmatic Zircons from the Iberian Pyrite Belt. Mineralogy and Petrology, 95, 47-69.

http://dx.doi.org/10.1007/s00710-008-0022-5

Rosa, M. L. S., Conceicão, H., Macambira, M. J. B., Galarza, M. A., Cunha, M. P., Menezes, R. C. L., Marinho, M. M., Cruz Filho, B. E., \& Rios, D. C. (2007). Neoproterozoic Anorogenic Magmatism in the Southern Bahia Alkaline Province of NE Brazil: U-Pb and Pb-Pb Ages of the Blue Sodalite Syenites. Lithos, 88-97. http://dx.doi.org/10.1016/j.lithos.2006.12.011

Rosa, M. L. S., Conceição, H., Marinho, M. M., Macambira, M. J. B., \& Marques, L. S. (2002). Geochronology of the South Bahia Alkaline Province (NE Brazil). Geochimica et Cosmochimica Acta, 66, A648.

Sheth, H. C., Torres-Alvarado, I. S., \& Verma, S. P. (2002). What Is the Calc-Alkaline Rock Series? International Geology Review, 44, 686-701. http://dx.doi.org/10.2747/0020-6814.44.8.686

Soliani, J. R. E., Koester, E., \& Fernandes, L. A. D. (2000). A geologia isotópica do Escudo Sul-rio-grandense-Parte I: métodos isotópicos e valor interpretativo. In M. Holz, \& L. F. Deros (Eds.), Geologia do Rio Grande do Sul (pp. 175-230). 
Volume Especial do CIGO/UFRGS. Porto Alegre.

Villas, R. N. N. (1982). Geocronologia das intrusões ígnea na bacia do rio Guamá, nordeste do Estado do Pará. In: Simpósio de Geologia da Amazônia, 2, Belém, Anais. Belém, SBG, 1, 233-247. 